\title{
Electroless Deposition of bis(4'-(4-Pyridyl)-2,2':6',2'-terpyridine)iron(II) Thiocyanate Complex onto Carbon Nanotubes Modified Glassy Carbon Electrode: Application to Simultaneous Determination of Ascorbic Acid, Dopamine and Uric Acid
}

\author{
M. A. Kamyabi, * O. Narimani and H. H. Monfared \\ Department of Chemistry, Zanjan University, P. O. Box 45195-313 Zanjan, Islamic Republic of Iran
}

\begin{abstract}
Um eletrodo de carbono vítreo modificado por nanotubos de carbono de paredes múltiplas (NTCPM) e pelo complexo tiocianato de bis(piterpi) ferro(II) (piterpi = 4'-(4-piridil)-2,2':6',2"'terpiridina) foi investigado através de métodos voltamétricos em solução de tampão acetato (pH 5). A performance do eletrodo modificado pelo complexo de ferro(II)/NTCPM foi avaliada por voltametria de pulso diferencial e microscopia eletrônica de varredura (MEV). O eletrodo de carbono vítreo modificado apresentou uma excelente resposta eletroquímica para ácido ascórbico (AA), dopamina (DA) e ácido úrico (AU). Os picos de oxidação em voltametria de pulso diferencial para AA e DA, DA e AU, AA e AU são separados por 210, 136 e 346 mV, respectivamente. Esta separação permite a determinação simultânea de AA, DA e AU. As correntes de pico anódico para AA, DA e AU aumentam linearmente com a concentração na faixa $1,10 \times 10^{-5}-1,50 \times 10^{-3} \mathrm{~mol} \mathrm{~L}^{-1}$, $9,0 \times 10^{-7}-1,20 \times 10^{-3} \mathrm{~mol} \mathrm{~L}^{-1}$ e $2,00 \times 10^{-6}-1,50 \times 10^{-3} \mathrm{~mol} \mathrm{~L}^{-1}$, respectivamente, com um coeficiente de correlação (r) sempre maior do que 0.998. Além disto, o eletrodo modificado também apresentou boa sensibilidade e estabilidade. Resultados satisfatórios foram alcançados para a determinação de AA em tabletes de vitamina C, DA em solução de dopamina de injeção, e AU em amostras de sangue humano.
\end{abstract}

A glassy carbon (GC) electrode modified by multi-walled carbon nanotubes (MWNTs) and bis(pyterpy)iron(II) thiocyanate complex (pyterpy = 4'-(4-pyridyl)-2,2':6',2"'-terpyridine) was investigated by voltammetric methods in acetate buffer solution $(\mathrm{pH} 5)$. Performances of the iron(II)-complex/MWNTs modified electrode were evaluated with differential pulse voltammetry and scanning electron microscopy (SEM). The modified glassy carbon electrode shows an excellent electrochemical response for ascorbic acid (AA), dopamine (DA) and uric acid (UA). The differential pulse voltammetry oxidation peaks for AA and DA, DA and UA, AA and UA are separated by 210,136 and $346 \mathrm{mV}$, respectively. This separation permits the simultaneous determination of AA, DA and UA. The anodic peak currents of AA, DA and UA increase linearly with concentration in the range of $1.10 \times 10^{-5}-1.50 \times 10^{-3} \mathrm{~mol} \mathrm{~L}^{-1}, 9.0 \times 10^{-7}-1.20 \times 10^{-3} \mathrm{~mol} \mathrm{~L}^{-1}$ and $2.00 \times 10^{-6}-1.50 \times 10^{-3} \mathrm{~mol} \mathrm{~L}^{-1}$, respectively, with a correlation coefficient (r) always higher than 0.998. In addition, the modified electrode also shows good sensitivity and stability. Satisfactory results were achieved for the determination of AA in vitamin C tablets, DA in dopamine injection solution and UA in human blood serum samples.

Keywords: multi-wall carbon nanotubes, bis(pyterpy)iron(II) thiocyanate complex, ascorbic acid, dopamine, uric acid

\section{Introduction}

Recently there has been a considerable effort in the development of voltammetric methods for the determination of ascorbic acid (AA), dopamine (DA) and uric acid (UA) in biological samples. Ascorbic acid is a water-soluble vitamin, and is a compound that takes part

*e-mail: makamyabi@gmail.com in many important life processes. It is one of the most important vitamins, due to its antioxidant and $\mathrm{pH}$ regulator properties often being added to various food products and pharmaceuticals. ${ }^{1,2}$ Ascorbic acid exists in mammalian brain in the presence of several other neurotransmitter amines including dopamine.

Dopamine plays an important role as a neurotransmitter (NTM) in the body. A deficiency in this NTM has been related to serious neurological disorders such as Parkinson 
disease and Schizophrenia. ${ }^{3-5}$ As a result, there is a continuing interest in the development of fast, sensitive and selective methods for the detection of DA. In particular, there has been much interest in the electrochemical methods because DA is electrochemically active and these methods are inexpensive and easy to employ. However, the determination of DA is complicated by the coexistence of many interfering compounds such as AA and UA, with AA being of particular significance. ${ }^{6} \mathrm{AA}$ is the most problematic because it is oxidized at similar potentials to DA and AA is present in concentrations that are several hundred times higher than DA in the living organism. Furthermore, the oxidized dopamine product, dopaminequinone, can be chemically reduced by AA to DA, which can be reoxidised at the electrode surface. ${ }^{7}$

Uric acid is a primary product of purine metabolism. Its abnormal concentration level in the human body causes many diseases, such as gout, hyperuricaemia and Lesch-Nyan disease. Elevated UA concentration in serum causes kidney damage and cardiovascular disease. Therefore, the research of UA determination is of great importance in reality.

AA, DA and UA usually coexist in physiological samples, ${ }^{8}$ but there is an overlapping oxidation potential on the solid electrodes. Therefore it is essential to develop simple and rapid methods for their determination in routine

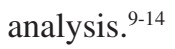

Among many methods for determination of UA, DA and AA in biological samples, voltammetric method has been shown to be a powerful tool. It is generally believed that direct redox reactions of these species on the bare electrodes are irreversible and high overpotentials are usually required for their amperometric detections. Moreover, the direct redox reactions of these species at the bare electrodes take place at very similar potentials and often suffer from a pronounced fouling effect, which results in rather poor selectivity and reproducibility. Correspondingly, various approaches have been developed to solve the problems. ${ }^{15-22}$

Carbon nanotubes (CNTs) with single or multiple walls have attracted considerable attention of the researchers since they were discovered by Iijima in $1991 .{ }^{23}$ They are molecular-scale wires with high electrical conductivity, high chemical stability, and extremely high mechanical strength and modulus. ${ }^{24}$

Utilization of these properties has lead to application of carbon nanotubes as scanning probes, ${ }^{25}$ electron field emission sources, ${ }^{26}$ actuators, ${ }^{27}$ nanoelectronic devices, ${ }^{28}$ batteries, ${ }^{29}$ nanotubes-reinforced materials, ${ }^{30}$ potential hydrogen storage material ${ }^{31}$ and chemical sensors. ${ }^{32}$

Due to its good electronic properties and electric conductivity, carbon nanotube has also been applied in electrochemical research. ${ }^{33-38}$ The direct electron transfer of enzymes such as cytochrome C, ${ }^{39}$ glucose oxidase (GOx), ${ }^{40}$ catalase,${ }^{41}$ horseradish peroxidase, myoglobin ${ }^{42}$ and hemoglobin ${ }^{43,44}$ can be observed in the presence of carbon nanotube. In addition, due to its ability of fast electron transfer, carbon nanotube also shows electrocatalytic activities towards many substances such as hydrogen peroxide $\left(\mathrm{H}_{2} \mathrm{O}_{2}\right), \mathrm{NADH}$, ascorbic acid, dopamine, catechol, homocysteine and thiocytosine. ${ }^{45-51}$ The good catalytic activities of these molecules as well as their good biocompatibility make possible to apply it in the fabrication of excellent biosensors.

In the current study, we report the electrochemical behavior of ascorbic acid, dopamine and uric acid on the surface of the iron(II) complex-MWNT modified GC electrode. It has been found that the modified glassy carbon electrode shows an excellent electrochemical response for ascorbic acid, dopamine and uric acid. This capability of the modified glassy carbon electrode makes it possible to determine AA, DA and UA simultaneously.

\section{Experimental}

\section{Reagents}

The ligand 4'-(4-pyridyl)-2,2':6',2''-terpyridine (pyterpy) and $\left.[\mathrm{Fe} \text { (pyterpy) })_{2}\right](\mathrm{SCN})_{2}$ complex (Scheme 1) were synthesized, purified and characterized as reported. ${ }^{52}$ A brief methodology for the synthesis of this ligand is as follows: i) 1,5-bis(2-pyridyl)-3-(4pyridyl)-1,5-pentanedione 2-acetylpyridine $(8.4 \mathrm{~mL})$ and 4-pyridinecarboxaldehyde $(3.0 \mathrm{~mL})$ are dissolved in ethanol $(35 \mathrm{~mL})$ in a $100 \mathrm{~mL}$ round-bottomed flask and a solution of sodium hydroxide $(2.0 \mathrm{~g})$ in water $(25 \mathrm{~mL})$ added. The mixture is stirred for $1 \mathrm{~h}$ at room temperature and then $30 \mathrm{~mL}$ of water added. This should give an off-white precipitate of 1,5-bis(2-pyridyl)-3-(4pyridyl)-1,5-pentanedione. Collect this by filtration, wash well with water and a little cold ethanol, and dry in a desiccator. ii) 4'-(4-pyridyl)-2,2': 6',2'"-terpyridine (pytpy) Heat a solution of 1,5-bis(2-pyridyl)-3-(4-pyridyl)-1,5pentanedione $(0.40 \mathrm{~g})$ and ammonium acetate $(5.0 \mathrm{~g})$ in $50 \mathrm{~mL}$ of ethanol to reflux for $2 \mathrm{~h}$. Allow the solution to cool and add $50 \mathrm{~mL}$ of water to precipitate the product. Recrystallise the product from a small amount of ethanol.

Multiwall carbon nanotubes, (MWNTs) (1-8 nm inner diameter, 2-25 $\mathrm{nm}$ outer diameter and BET of $\left.285 \mathrm{~m}^{2} \mathrm{~g}^{-1}\right)$, and $1 \mu \mathrm{m}$ length were obtained from research institute of petroleum industry of Iran. All chemicals were of analytical-reagent grade from Merck or Fluka and were used without further purification. Triply distilled water was 


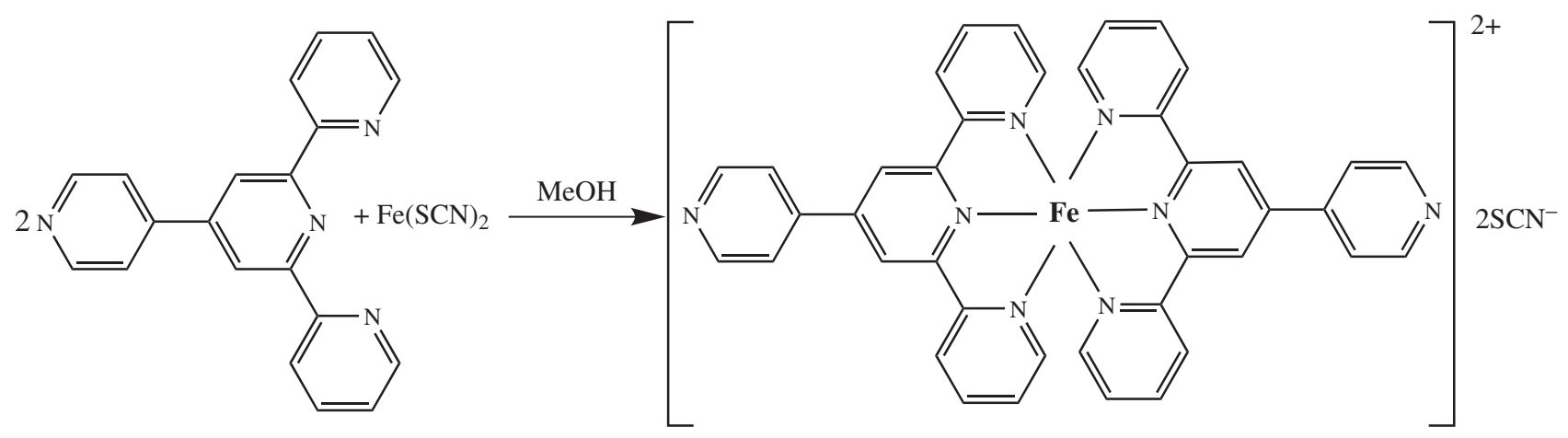

used to prepare buffer and reagent solutions. Stock solutions of AA, DA and UA were freshly prepared as required in $0.10 \mathrm{~mol} \mathrm{~L}^{-1}$ of appropriate buffer solution. In these experiments, $0.10 \mathrm{~mol} \mathrm{~L}^{-1}$ acetate was used for $\mathrm{pH} 4$ and 5, and $0.10 \mathrm{~mol} \mathrm{~L}^{-1}$ phosphate for $\mathrm{pH} \mathrm{3,6}$ and 7. The prepared solutions were purged with pure nitrogen gas $(99.999 \%)$ for $5 \mathrm{~min}$ before the voltammetric measurements. Voltammetric experiments were carried out in the buffered solutions of AA, DA and UA, deoxygenated by purging the pure nitrogen. During the experiments, nitrogen gas was passed over the surface of the test solutions in order to avoid entrance of oxygen into the solution.

\section{Apparatus}

Voltammetric experiments were performed with a Metrohm computrace voltammetric analyzer model 757 VA. A conventional three-electrode system including glassy carbon electrode modified with MWNTs and bis(pyterpy)iron(II) thiocyanate complex as working electrode, an $\mathrm{Ag} / \mathrm{AgCl}$ (saturated $\mathrm{KCl}$ ) and a platinum wire were used as reference and counter electrode, respectively. A digital $\mathrm{pH} / \mathrm{mV}$ meter model 780 Metrohm was applied for the preparation of the buffer solution. A Carl Zeiss CEM 902A, Germany, device was used for transmission electron microscopy (TEM) and scanning electron microscopy (SEM) was carried out on a Philips device (XL30). Electrochemical experiments were carried out at room temperature $25.0 \pm 0.1^{\circ} \mathrm{C}$.

\section{Preparation of the modified electrode}

The GC (glassy carbon) electrode ( $2 \mathrm{~mm}$ diameter) was carefully polished with aluminum on polishing cloth. The electrode was placed in ethanol and subjected to vibration to remove adsorbed particles. Then 15 cycle scans were carried out in the potential range of -2.0 to $+2.0 \mathrm{~V}$ versus reference electrode in a solution of $1.0 \mathrm{~mol} \mathrm{~L}^{-1}$ sulfuric acid
$\left(\mathrm{H}_{2} \mathrm{SO}_{4}\right) \cdot{ }^{39}$ Finally, the electrode was heated for $5 \mathrm{~min}$ at $50{ }^{\circ} \mathrm{C}$ in oven. MWNTs (4 mg) were dispersed in $10 \mathrm{~mL}$ dimethyl sulfoxide (DMSO) by ultrasonic agitation for about $30 \mathrm{~min}$ to give a $0.4 \mathrm{mg} \mathrm{mL}^{-1}$ black suspension. The MWNTs modified electrode was prepared by casting $30 \mu \mathrm{L}$ of the MWNTs on the surface of GC electrode, which was dried in air for $24 \mathrm{~h}$ at room temperature. When the DMSO was volatilized, a MWNTs film was formed. The iron(II) complex-MWNTs-modified GC electrode was prepared by the following procedure. The MWNTs-modified GC electrode was dipped in $1 \mathrm{mmol} \mathrm{L}^{-1}$ acetonitrile solution of bis(pyterpy)iron(II) thiocyanate complex for 60-120 s. The modified electrode, then, was rinsed with distilled water and was dried for $1 \mathrm{~h}$ at room temperature. The iron(II) complex-MWNTs-modified GC electrode was

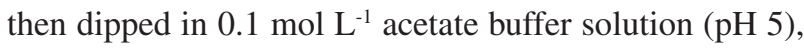
and consecutive cyclic potential scan ( 15-20 cycles) were performed in the potential range -1.0 to $+1.0 \mathrm{~V}$ with a scan rate of $100 \mathrm{mV} \mathrm{s}^{-1}$ to obtain a stable cyclic voltammogram. The pretreatment of activation is believed to result in the increase in surface roughness by removal of the surface contaminants and inhibitory layers which hinder electron transfer. ${ }^{39,53,54}$ This activation also breaks the end caps of carbon nanotubes, exposing new carbon plane and leading to electrocatalytic activity. ${ }^{55}$ The modified electrode was stored in pH 5 buffer solution at $4{ }^{\circ} \mathrm{C}$ before use.

\section{Results and Discussion}

\section{Characterization of the iron(II)-complex/MWNTs-modified GC electrode}

The iron(II)-complex/multi-walled nanotubes modified GC electrode was first characterized by TEM and SEM. Figure 1 (A and B) shows a typical TEM image of the MWNTs which were dispersed in DMF by sonication. It is clear that MWNTs are highly entangled with the diameter of several tens of nanometers. A typical scanning electron 
(A)

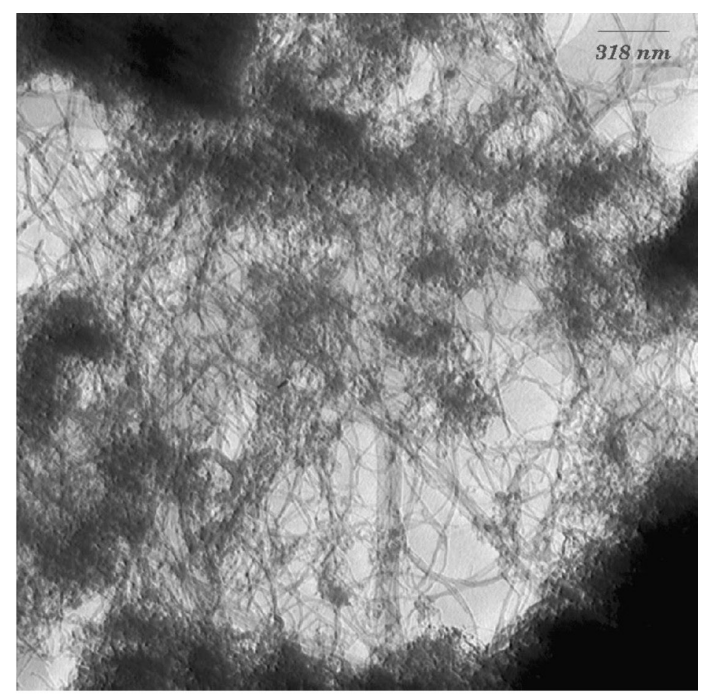

(B)

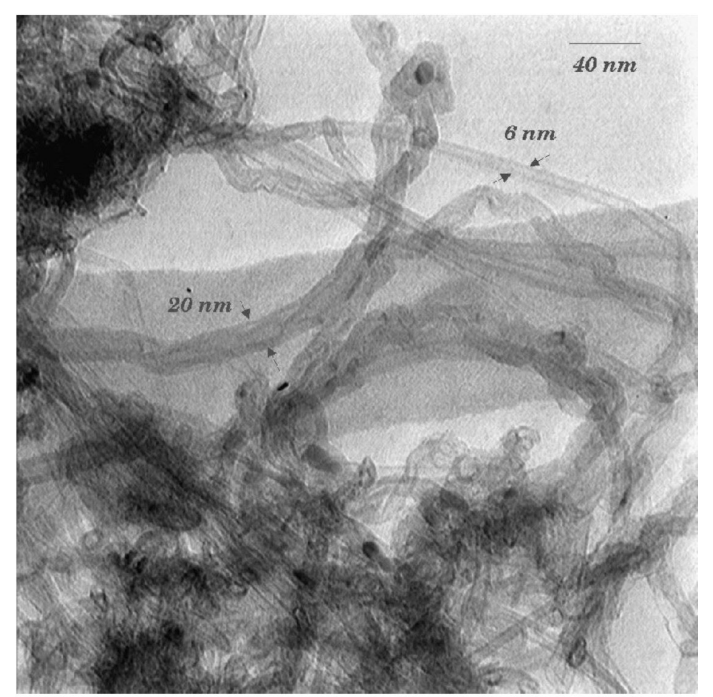

(C)

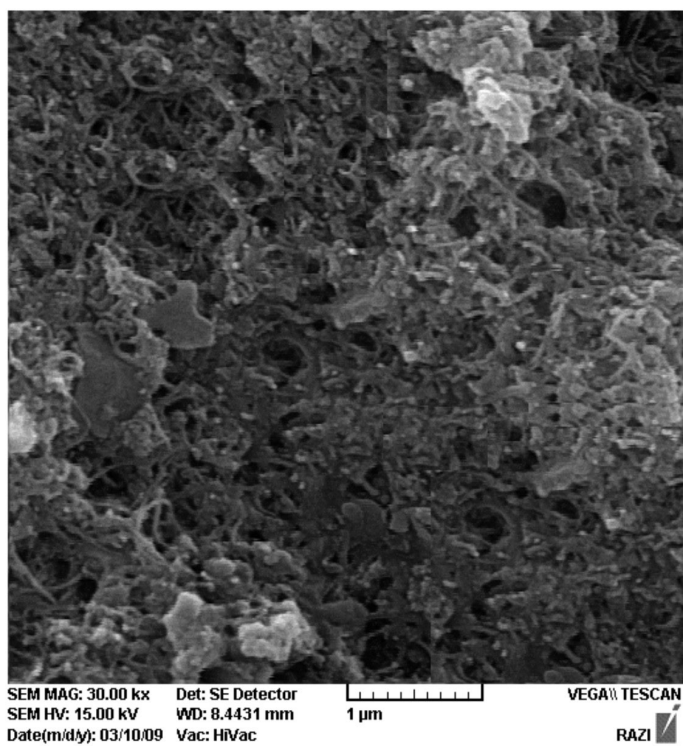

Figure 1. TEM images of (A, B) MWNT in DMF and (C) SEM image of the iron(II)-complex/MWNTs composite film over GC electrode. micrograph image of the iron(II)-complex/MWNTsmodified GC film electrode surface, is shown in Figure 1c. It is clearly seen that the glassy carbon disk surface is completely and homogeneously coated by the iron(II)complex/MWNTs composite film.

Electrochemical behavior of AA, DA and UA at the iron(II)complex/MWNTsmodified GC electrode

The cyclic voltammograms of ascorbic acid, dopamine and uric acid at a bare GC and the iron(II)-complex/ MWNTs-modified GC electrodes are shown in Figure 2.

The oxidation peak potentials of AA, DA and UA are very close to each other at a bare GC electrode (Figure 2a). The electrochemical reactions of AA, DA and UA are also quasireversible or irreversible. This finding indicates the slow electron transfer rates for the oxidation of these biomolecules at a bare GC electrode. Such sluggish electron

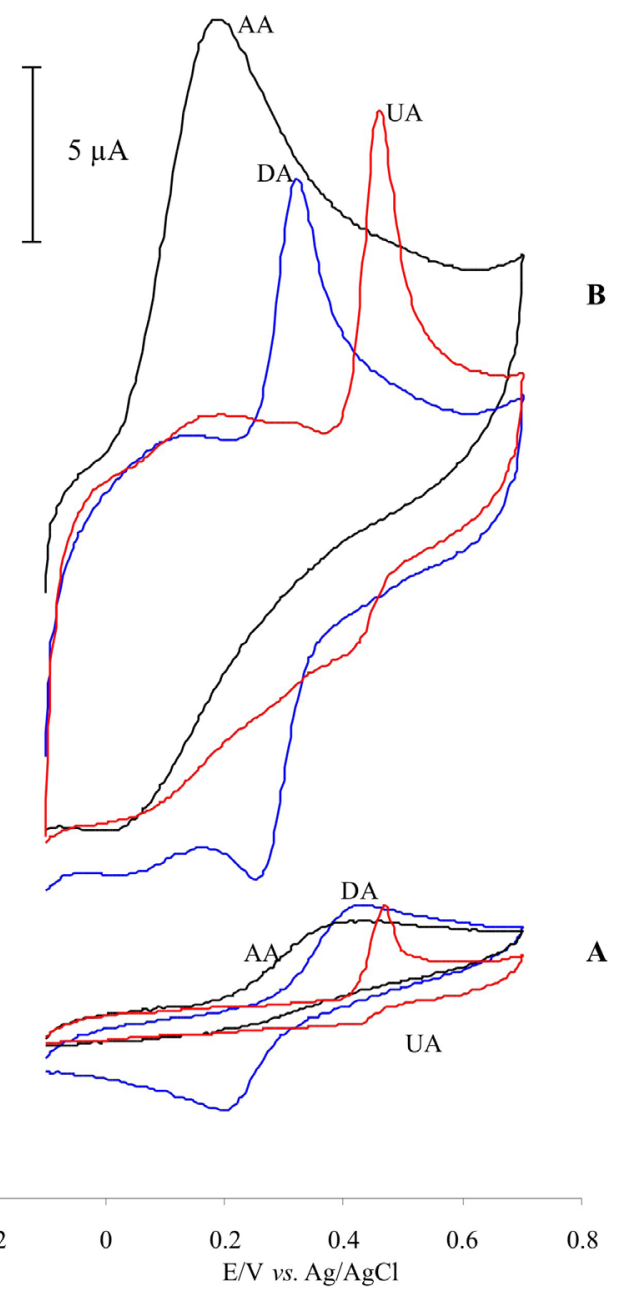

Figure 2. Cyclic voltammograms of ascorbic acid $\left(0.5 \mathrm{mmol} \mathrm{L}^{-1}\right)$, dopamine $\left(100 \mu \mathrm{mol} \mathrm{L}^{-1}\right)$ and uric acid $\left(0.5 \mathrm{mmol} \mathrm{L}^{-1}\right)$ at (A) bare GC electrode (B) the iron(II)-complex/MWNTs modified electrode in $0.1 \mathrm{~mol} \mathrm{~L}^{-1}$ acetate buffer solution (pH 5.0). Scan rate was $100 \mathrm{mV} \mathrm{s}^{-1}$. 
transfer kinetics may be related to the electrode fouling caused by the deposition of AA, DA, UA and their oxidation products on the electrode surface. ${ }^{56}$ For dopamine, the cathodic and anodic peaks appeared on GCE at $192 \mathrm{mV}$ and $420 \mathrm{mV}$, respectively. The peak potential separation is about $280 \mathrm{mV}$. Moreover, on the electrode surface, DA is oxidized at about the same potential as AA; and the homogeneous catalytic oxidation of AA with DA in the vicinity of the electrode surface causes the main interference of AA for the detection of DA. Therefore, the AA oxidation peak is not distinguishable in the presence of DA. ${ }^{8}$ In a comparison with the GC electrode, the reversibility of DA at the iron(II)complex/MWNTs ${ }^{8}$ modified GC electrode is considerably improved, so that the anodic and cathodic peak potentials separation becomes $70 \mathrm{mV}$, and the $i_{\mathrm{pa}} / i_{\mathrm{pc}}$ ratio becomes near unity (Figure $2 b$ ). The peak potential due to the oxidation of AA occurs at $180 \mathrm{mV}$ (vs. $\mathrm{Ag} / \mathrm{AgCl}, \mathrm{KCl}$, $3 \mathrm{~mol} \mathrm{~L}^{-1}$ ) which is about $200 \mathrm{mV}$ more negative than the GC electrode. In the case of UA, a sharp oxidation peak at $465 \mathrm{mV}$ and a small reduction peak at $418 \mathrm{mV}$ occurred at the iron(II)-complex/MWNTs-modified GC electrode, i.e., the negative shift with much enhanced anodic peak current in comparison with the GC electrode.

These findings showed high enhancement in the electron transfer rates of AA, DA and UA on the iron(II)complex/MWNTs-modified GC electrode (Figure 2b). Apparent peak shapes for AA, DA and UA at the iron(II)complex/MWNTs-modified GC electrode are improved against those of the GC electrode. So the well-shaped peaks of these species could be observed in the presence of iron(II)- complex/MWNTs-modified GC and provided an excellent electrochemical reactivity. Moreover, no fouling of the modified electrode was observed due to the oxidation of AA, DA or UA.

\section{Dependence of the voltammetric resolution of $A A, D A$ and} $U A$ at the iron(II)-complex/MWNTs modified GC electrode on $\mathrm{pH}$

To optimize the electrochemical response of the modified electrode for the electrocatalytic oxidation of AA, DA and UA, the effects of $\mathrm{pH}$ on the electrode response and the oxidation potential were investigated by cyclic voltammetry in the solution containing $1.0 \mathrm{mmol} \mathrm{L}^{-1}$ of analyte. With increasing $\mathrm{pH}$ (3-9), the peak potentials of all three species AA, DA and UA were shifted to more negative values (not shown). This is a consequence of a deprotonation step involved in the oxidation processes and is facilitated at higher $\mathrm{pH}$. For AA and DA, the anodic peak potential difference (Epa) increased up to $\mathrm{pH} 5$ with increasing in $\mathrm{pH}$ and then decreased with more increase in
$\mathrm{pH}$ (Figure 3). As Figure 3 shows, in the $\mathrm{pH}$ range 3-9 the anodic peak potential difference (Epa) in the instance of DA and UA, was almost constant. However, the iron(II)complex showed a better electrocatalytic activity for the oxidation of all three components in solution with a $\mathrm{pH}$ equal to 5 which had the maximum anodic peak potential differences and the sensitivities were also enhanced by working at this $\mathrm{pH}$ where the currents are maximum.

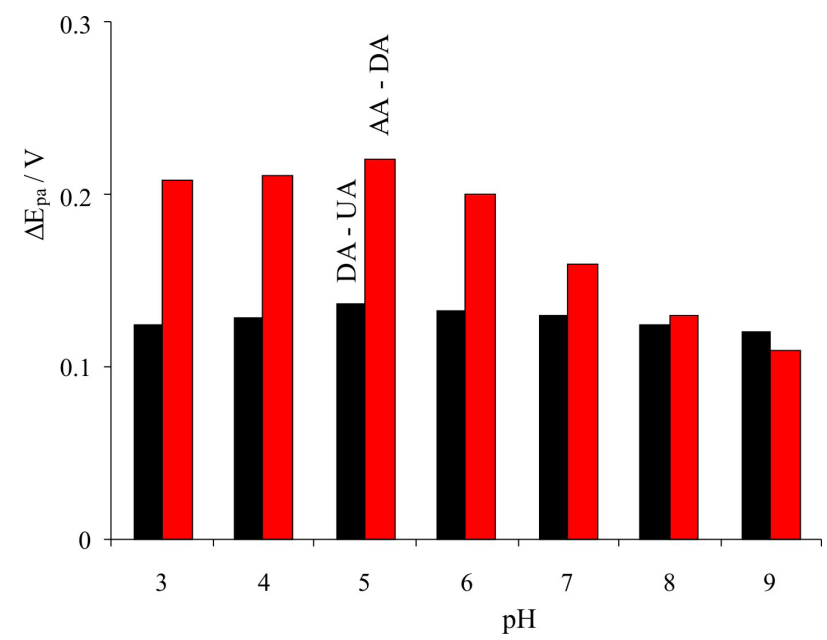

Figure 3. Anodic peak potential differences (Epa) between AA-DA and DA-UA of ascorbic acid $\left(0.5 \mathrm{mmol} \mathrm{L}^{-1}\right)$, dopamine $\left(100 \mu \mathrm{mol} \mathrm{L}^{-1}\right)$ and uric acid $\left(0.5 \mathrm{mmol} \mathrm{L}^{-1}\right)$ at the iron(II)-complex/MWNTs modified electrode in $0.1 \mathrm{~mol} \mathrm{~L}^{-1}$ acetate buffer solution (pH 5.0). Scan rate was $100 \mathrm{mV} \mathrm{s}^{-1}$.

The $\mathrm{pH}$ effects on peak potentials (Epa) for the oxidation of AA, DA and UA on the iron(II)-complex/ MWNTs-modified GC electrode are shown in Figure 4. All species Epa shifted to lower potential by increasing

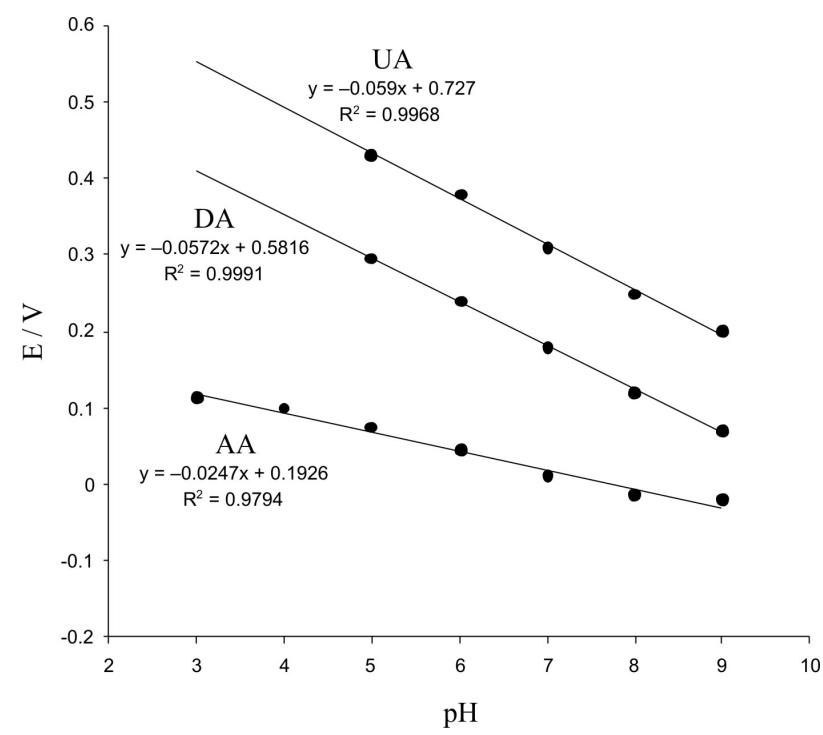

Figure 4. Dependence of the oxidation peak potentials of $0.5 \mathrm{mmol} \mathrm{L}^{-1}$ ascorbic acid, $100 \mu \mathrm{mol} \mathrm{L}^{-1}$ dopamine and $0.5 \mathrm{mmol} \mathrm{L}^{-1}$ uric acid on $\mathrm{pH}$ at the iron(II)-complex/MWNTs modified GC electrode in $0.1 \mathrm{~mol} \mathrm{~L}^{-1}$ acetate buffer solution (pH 5.0). Scan rate was $100 \mathrm{mVs}^{-1}$. 
$\mathrm{pH}$. The calculated $[\partial \mathrm{Epa} / \partial \mathrm{pH}]=-24.7$ for $\mathrm{AA}$, suggests a two-electron, one-proton oxidation process. ${ }^{57,58}$ However, the calculated $[\partial \mathrm{Epa} / \partial \mathrm{pH}]$ for DA and UA are -57.2 , $-59.0 \mathrm{mV} \mathrm{pH}{ }^{-1}$, respectively. These are close to that of expected for monoelectronic/monoprotonic electrode reaction $\left(-59.2 \mathrm{mV} \mathrm{pH}^{-1}\right.$ at $\left.25^{\circ} \mathrm{C}\right)$ and shows the electron transfer was accompanied by an equal number of protons.

The stability of electrocatalytic activity of the modified GC electrode towards oxidation of AA, DA and UA were checked separately by repetitive scanning in the acetate buffer pH 5.0 solutions of each of species, between 0.0 to $0.7 \mathrm{~V}$ at scan rate of $100 \mathrm{mV} \mathrm{s}^{-1}$. The peak current was considered as a factor in indicating the stability of the modified electrode at various conditions of operation. The anodic peak current showed a small decrease (about 2-3\%, not shown) after twenty cyclic voltamograms in the $\mathrm{pH} 5.0$ acetate buffer solution. In addition, the electrode could also withstand if stored in solution for a period of time (at least 2 week) and the electrocatalytic currents remained almost unchanged. These phenomena show that the modified electrode is stable in aqueous solution. The high stability of the adsorbed iron(II)-complex against desorption in aqueous solution, is related to the chemical and mechanical stability of nanotube film. This stability probably is due to the strong interaction of aromatic groups of the iron(II)-complex with $\pi$-staking of carbon nanotubes and the possible interaction between the iron(II)-complex and activated carbon nanotubes..$^{52}$

\section{Differential pulse voltammetry}

Differential pulse voltammetry (DPV) was used for simultaneous determination of AA, DA and UA at the iron-complex/MWNTs modified GC electrode because of its higher current sensitivity and better resolution than the cyclic voltammetry. For this purpose, DPV was carried out in the potential range of -50 to $550 \mathrm{mV}$. Figure 5 shows the DPV of a mixture of AA $\left(0.5 \mathrm{mmol} \mathrm{L}^{-1}\right), \mathrm{DA}\left(0.1 \mathrm{mmol} \mathrm{L}^{-1}\right)$ and UA $\left(0.5 \mathrm{mmol} \mathrm{L}^{-1}\right)$ at a bare GC electrode, MWNTsmodified GC electrode and the iron-complex/MWNTsmodified GC electrode in $0.1 \mathrm{~mol} \mathrm{~L}^{-1}$ acetate buffer solution (pH 5). It is obvious that the oxidation peak potentials of AA, DA and UA are very close to each other at a bare GC electrode and MWNTs-modified GC electrode (Figure 5, curves A and B). Three well-defined peaks at about 72, 298, and $460 \mathrm{mV} v s . \mathrm{Ag} / \mathrm{AgCl}\left(\mathrm{KCl}, 3.0 \mathrm{~mol} \mathrm{~L}^{-1}\right)$ were observed at the iron(II)-complex/MWNTs modified electrode (Figure 5, curve C), which correspond to the differential pulse voltammograms of AA, DA, and UA, respectively. Peak separations of 226, 162 and $388 \mathrm{mV}$ between DA and AA, DA and UA, and UA and AA, respectively, allow us to detect AA, DA and UA simultaneously by using DPV.

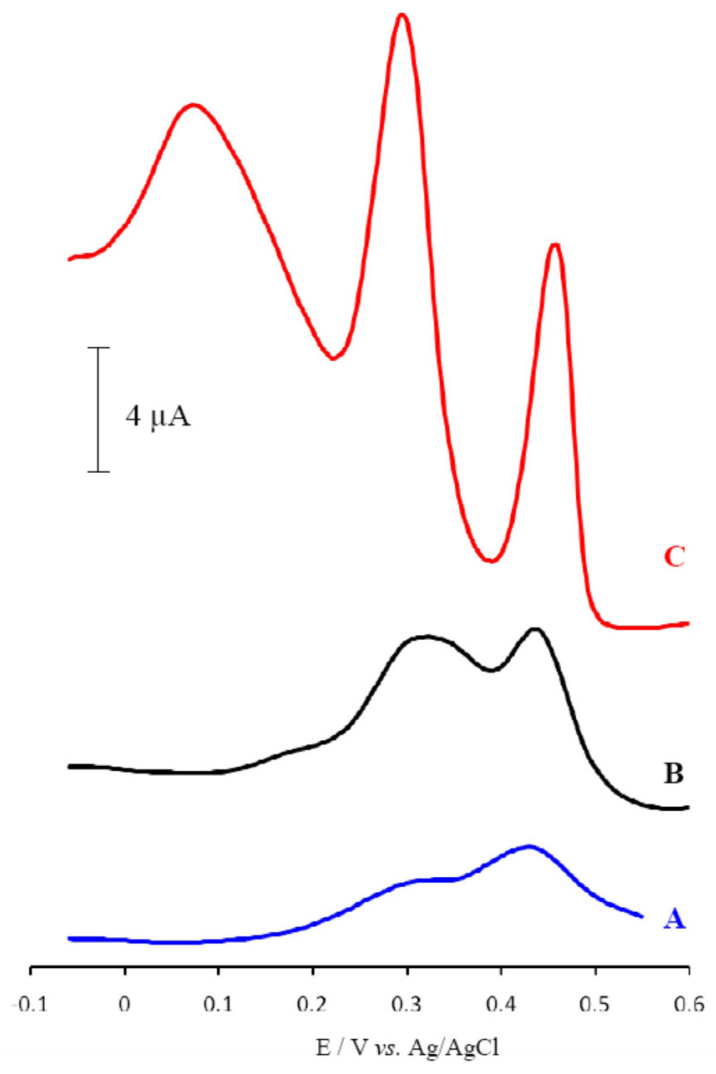

Figure 5. Differential pulse voltammograms of mixture of AA $\left(0.5 \mathrm{mmolL}^{-1}\right)$, DA $\left(100 \mu \mathrm{mol} \mathrm{L}^{-1}\right)$ and $\mathrm{UA}\left(0.5 \mathrm{mmol} \mathrm{L}^{-1}\right)$ at (A) a bare GC electrode, (B) MWNTs modified GC electrode, (C) the iron(II)-complex/MWNTs modified GC electrode in $0.1 \mathrm{~mol} \mathrm{~L}^{-1}$ acetate buffer solution ( $\mathrm{pH} 5.0$ ). Scan rate was $100 \mathrm{mV} \mathrm{s}^{-1}$.

The linear ranges for the determination of $\mathrm{AA}$, DA and UA using DPV were $1.10 \times 10^{-5}-1.50 \times 10^{-3}$, $9.00 \times 10^{-7}-1.20 \times 10^{-3}$ and $2.00 \times 10^{-6}-1.50 \times 10^{-3} \mathrm{~mol} \mathrm{~L}^{-1}$, respectively. The limit of detection equals $3 \mathrm{sb} \mathrm{m}^{-1}$, where $s b$ is the standard deviation of the blank signal and $\mathrm{mol} \mathrm{L}^{-1}$ is the slope of the calibration curve for the proposed method. The theoretical detection limits, of the proposed method, for AA, DA and UA were $8.00 \times 10^{-6}, 2.00 \times 10^{-7}$, and $1.0 \times 10^{-6} \mathrm{~mol} \mathrm{~L}^{-1}$, respectively. The electrooxidation processes of AA, DA and UA in a mixture when the concentration of one species changed, while those of the other two species were kept constant were also investigated. Figure 6 shows the DPV for the determination of AA, DA, and UA in the mixture while the concentration of one species is being changed, and those of the other two species were kept constant. The slope of the linear regression line for the calibration graph of each species is nearly equal to that without the other species, indicating that they do not interfere in the determination of each other. Table 1 shows a comparison between previously reported modified electrodes for determination of AA, DA and UA and the iron(II)-complex/MWNTs 

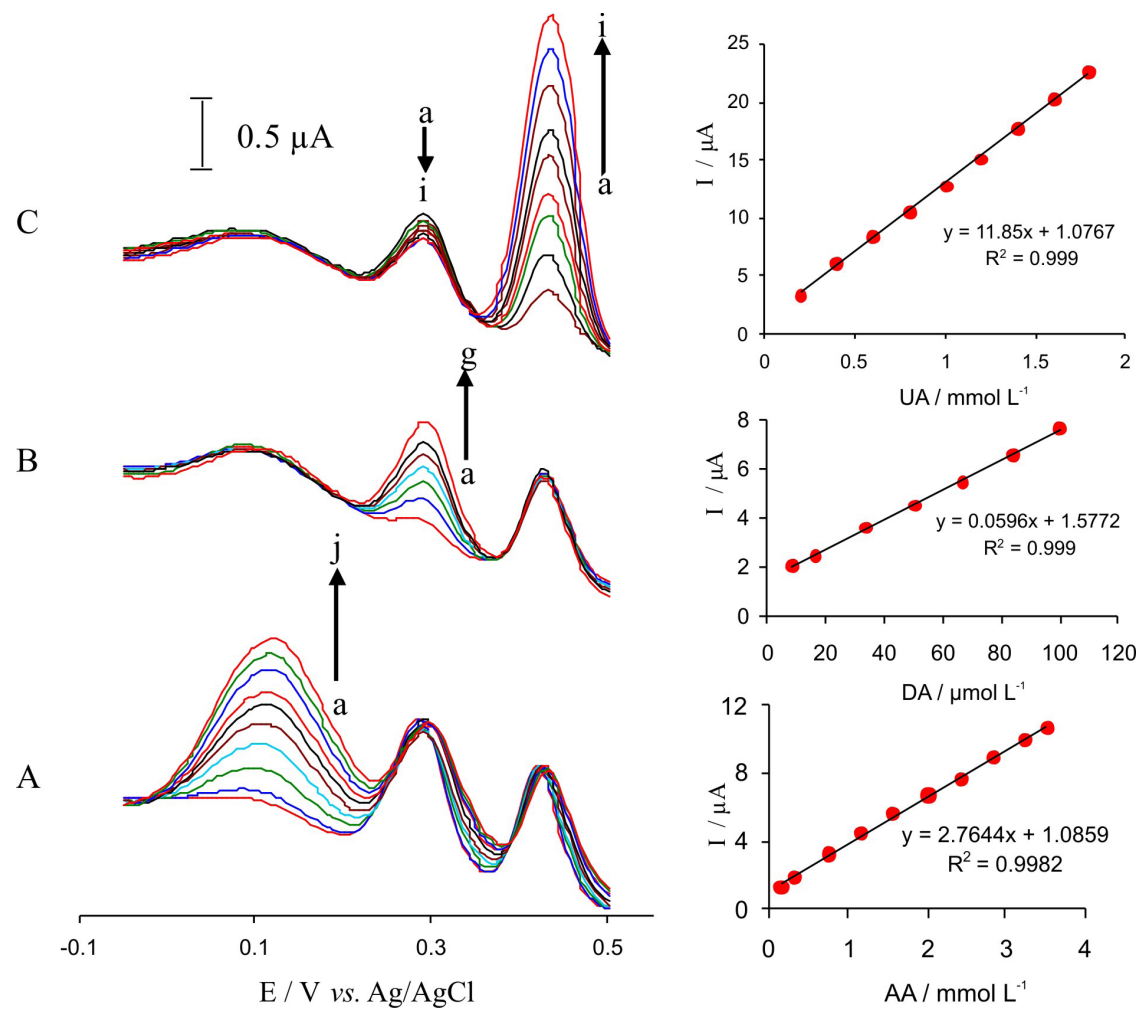

Fiure 6. (A) Differential pulse voltammograms of AA at the iron(II)-complex/MWNTs modified GC electrode in the presence of $100 \mu \mathrm{mol} \mathrm{L}^{-1} \mathrm{DA}$ and $0.5 \mathrm{mmol} \mathrm{L}^{-1} \mathrm{UA}$ in $0.1 \mathrm{~mol} \mathrm{~L}^{-1}$ acetate buffer, $\mathrm{pH} 5.0$, AA concentrations (from a to j): $0.16,0.33,0.75,1.17,1.58,2.00,2.42,2.83,3.25$ and $3.50 \mathrm{mmol} \mathrm{L}^{-1}$ (B) Differential pulse voltammograms of DA at the iron(II)-complex/MWNTs modified GC electrode in the presence of $0.5 \mathrm{mmol} \mathrm{L}^{-1} \mathrm{AA}^{\text {and }} 0.5 \mathrm{mmol} \mathrm{L}^{-1}$ UA in $0.1 \mathrm{~mol} \mathrm{~L}^{-1}$ acetate buffer, pH 5.0. DA concentrations (from a to g): $0.05,0.16,0.34,0.50,0.67,0.83$, and $1.00 \mathrm{mmol} \mathrm{L}^{-1}$. (C) Differential pulse voltammograms of UA at the iron(II)-complex/MWNTs modified GC electrode in the presence of $0.5 \mathrm{mmol} \mathrm{L}^{-1} \mathrm{AA}$ and $100 \mu \mathrm{mol} \mathrm{L}^{-1} \mathrm{DA}$ in $0.1 \mathrm{~mol} \mathrm{~L}^{-1}$ acetate buffer, $\mathrm{pH}$ 5.0. UA concentrations (from a to i): $0.20,0.40,0.60,0.80,1.00,1.20,1.40,1.60$ and $1.80 \mathrm{mmol} \mathrm{L}^{-1}$.

Table 1. Comparison of analytical parameters of several modified electrodes for AA, DA and UA determination

\begin{tabular}{|c|c|c|c|c|c|c|}
\hline Electrode & Method & Analyte & $\begin{array}{l}\text { Linear range } \\
\left(\mu \mathrm{mol} \mathrm{L} \mathrm{L}^{-1}\right)\end{array}$ & $\begin{array}{c}\text { Limit of } \\
\text { detection } \\
\left.(\mu \mathrm{mol} \mathrm{L})^{-1}\right)\end{array}$ & $\begin{array}{c}\text { Sensitivity } \\
\left(\mu \mathrm{A} \mu \mathrm{mol}^{-1} \mathrm{~L}\right)\end{array}$ & Reference \\
\hline $\begin{array}{l}\text { Modified carbon paste electrode by tetrabromo- } p \\
\text { benzoquinone }\end{array}$ & DPV & $\begin{array}{l}\text { AA } \\
\text { DA } \\
\text { UA }\end{array}$ & $\begin{array}{l}10-600 \\
10-100 \\
10-100\end{array}$ & $\begin{array}{c}0.62 \\
- \\
-\end{array}$ & $\begin{array}{c}0.005 \\
0.0074 \\
0.0022\end{array}$ & 19 \\
\hline $\begin{array}{l}\text { Poly (3-(5-chloro-2-hydroxyphenylazo)-4,5 } \\
\text { dihydroxynaphthalene-2,7-disulfonic acid) film }\end{array}$ & DPV & $\begin{array}{l}\text { AA } \\
\text { DA } \\
\text { UA }\end{array}$ & $\begin{array}{c}5-240 \\
5-280 \\
0.1-180\end{array}$ & $\begin{array}{l}1.43 \\
2.9 \\
0.16\end{array}$ & $\begin{array}{l}0.013 \\
0.057 \\
0.353\end{array}$ & 34 \\
\hline $\begin{array}{l}\text { Oxidation in mild } \\
\text { acidic media }\end{array}$ & $\mathrm{CV}$ & $\begin{array}{l}\text { AA } \\
\text { DA } \\
\text { UA }\end{array}$ & $\begin{array}{c}197-988 \\
1.97-9.78 \\
19.7-97.8\end{array}$ & $\begin{array}{l}- \\
- \\
-\end{array}$ & $\begin{array}{l}- \\
- \\
-\end{array}$ & 33 \\
\hline Dopamine solutions-phosphate buffer & DPV & $\begin{array}{l}\text { AA } \\
\text { DA } \\
\text { UA }\end{array}$ & $\begin{array}{c}25-500 \\
1-20 \\
2.5-20\end{array}$ & $\begin{array}{c}13 \\
0.11 \\
1.4\end{array}$ & $\begin{array}{c}0.007 \\
0.006 \\
0.09\end{array}$ & 39 \\
\hline $\begin{array}{l}\text { Novel choline and acetylcholine modified glassy } \\
\text { carbon }\end{array}$ & DPV & $\begin{array}{l}\text { DA } \\
\text { AA }\end{array}$ & $\begin{array}{r}0.7-5 \\
7-90\end{array}$ & $\begin{array}{l}0.3 \\
0.9\end{array}$ & - & $14 \mathrm{I}$ \\
\hline CPE/CNF/Pdnano & DPV & $\begin{array}{l}\text { AA } \\
\text { DA } \\
\text { UA }\end{array}$ & $\begin{array}{c}50-4000 \\
0.5-160 \\
2-200\end{array}$ & $\begin{array}{l}15 \\
0.2 \\
0.7\end{array}$ & $\begin{array}{l}- \\
- \\
-\end{array}$ & 54 \\
\hline $\mathrm{Pt} / \mathrm{PF} / \mathrm{Pdnano}$ & DPV & $\begin{array}{l}\text { AA in presence } \\
\text { of ACOP } \\
\text { DA in presence } \\
\text { of ACOP }\end{array}$ & $\begin{array}{l}50-1000 \\
0.5-100\end{array}$ & $\begin{array}{l}7.1 \\
0.5\end{array}$ & $\begin{array}{c}5.92 \\
0.0213\end{array}$ & 59 \\
\hline Iron(II)-complex / MWNTs/GC & DPV & $\begin{array}{l}\text { AA } \\
\text { DA } \\
\text { UA }\end{array}$ & $\begin{array}{c}11-1500 \\
0.9-1200 \\
2-1500\end{array}$ & $\begin{array}{c}8 \\
0.2 \\
1\end{array}$ & $\begin{array}{c}0.0118 \\
0.059 \\
0.0027\end{array}$ & (This work) \\
\hline
\end{tabular}


modified GC electrode. As can be seen the proposed modified electrode shows somewhat similar (or worse) performances, in some cases, or superior ones, in most cases, than the previously reported modified electrodes.

\section{Interferences}

For investigating the interference, several compounds were selected. If the tolerance limit was taken as the maximum concentration of the foreign substances, which causes an approximately $5 \%$ relative error, for $0.5 \mathrm{mmol} \mathrm{L}^{-1}$ AA, $0.1 \mathrm{mmol} \mathrm{L}^{-1} \mathrm{DA}$, and $0.5 \mathrm{mmol} \mathrm{L}^{-1} \mathrm{UA}$, no interference was observed for the following compounds $\left(\mu \mathrm{mol} \mathrm{L}^{-1}\right)$ : $\mathrm{K}^{+}$, $\mathrm{Ca}^{2+}, \mathrm{Mg}^{2+}, \mathrm{Zn}^{2+}$, starch, citric acid, cysteine, glucose. The results are listed in Table 2 .

Table 2. Interferences of some foreign substances for $0.5 \mathrm{mmol} \mathrm{L}^{-1} \mathrm{AA}$, $100 \mu \mathrm{mol} \mathrm{L}-1$ DA, and $0.5 \mathrm{mmol} \mathrm{L}^{-1} \mathrm{UA}$

\begin{tabular}{lc}
\hline Foreign substances & Tolerance level $(\mu \mathrm{mol} \mathrm{L}-1)$ \\
\hline Starch & 400 \\
$\mathrm{~K}^{+}, \mathrm{Mg}^{2+}, \mathrm{Ca}^{2+}, \mathrm{Zn}^{2+}$ & 250 \\
Citric acid & 100 \\
Cysteine & 40 \\
Glucose & 50 \\
\hline
\end{tabular}

Determination of AA in vitamin $C$ injection, DA in dopamine hydrochloride injection solutions and UA in human blood serum

In order to demonstrate the capability of this modified electrode for the catalytic oxidation of AA, DA and UA in real samples, we examined this ability in the voltammetric determination of AA, DA and UA in some pharmaceutical preparations, such as vitamin $\mathrm{C}$ injection solution (standard content $100 \mathrm{mg} \mathrm{mL}^{-1} \mathrm{AA}, 5 \mathrm{~mL}$ per injection), (Daro Pakhsh Co.), dopamine hydrochloride injection (DHI) solution (standard content of $40 \mathrm{mg} \mathrm{mL}$ DA, $5 \mathrm{~mL}$ per injection), (Rasht Co.) and human blood serum. Human blood serum samples were centrifuged before the experiment. All samples were diluted with acetate buffer ( $\mathrm{pH} \mathrm{5.0)}$ and then appropriate amounts of these diluted samples were transferred to the electrochemical cell to determine each species using DPV. The standard addition technique was employed for AA, DA and UA determination. The results of AA, DA and UA determinations in the real samples and the spiked samples with AA, DA or UA standard solutions are shown in Tables 3 and 4 . The recovery and precision were acceptable, revealing that the modified electrode could be efficiently applied for determination of AA, DA and UA in pharmaceutical samples.

Table 3. Recovery results obtained for determination of AA and DA and the spiked AA and DA in injection solutions $(\mathrm{n}=5)$

\begin{tabular}{|c|c|c|c|}
\hline $\begin{array}{l}\text { AA labeled concentration }\left(\mathrm{mmol} \mathrm{L}^{-1}\right) \\
\text { Content }\end{array}$ & Added concentration $\left(\mathrm{mmol} \mathrm{L}^{-1}\right)$ & AA found $\left(\mathrm{mmol} \mathrm{L}^{-1}\right)^{\mathrm{a}}$ & Recovery $(\%)$ \\
\hline \multirow{5}{*}{0.50} & 0.00 & $0.47 \pm 0.013$ & 94 \\
\hline & 0.50 & $0.97 \pm 0.014$ & 97 \\
\hline & 1.00 & $1.47 \pm 0.02$ & 98 \\
\hline & 1.50 & $1.98 \pm 0.02$ & 99 \\
\hline & 2.00 & $2.42 \pm 0.022$ & 97 \\
\hline $\begin{array}{l}\text { DA labeled concentration }\left(\mathrm{mmol} \mathrm{L}^{-1}\right) \\
\text { Content }\end{array}$ & added concentration $\left(\mathrm{mmol} \mathrm{L}^{-1}\right)$ & DA found $(\mathrm{mM})^{\mathrm{a}}$ & Recovery (\%) \\
\hline \multirow{5}{*}{$1.00 \times 10^{-2}$} & 0 & $(9.80 \pm 0.21) \times 10^{-3}$ & 98 \\
\hline & $2.00 \times 10^{-2}$ & $(2.90 \pm 0.32) \times 10^{-2}$ & 97 \\
\hline & $4.00 \times 10^{-2}$ & $(5.00 \pm 0.28) \times 10^{-2}$ & 100 \\
\hline & $6.00 \times 10^{-2}$ & $(7.10 \pm 0.34) \times 10^{-2}$ & 101 \\
\hline & $8.00 \times 10^{-2}$ & $(9.10 \pm 0.34) \times 10^{-2}$ & 101 \\
\hline
\end{tabular}

${ }^{\mathrm{a}}$ Results are expressed as mean value $\pm \mathrm{SD}$, based on five replicate.

Table 4. Recovery results obtained for determination of UA and the spiked UA in human blood serum $(n=5)$

\begin{tabular}{lccc}
\hline $\begin{array}{l}\text { Sample detected UA }\left(\mathrm{mmol} \mathrm{L}^{-1}\right) \\
\text { Content }\end{array}$ & Added concentration $\left(\mathrm{mmol} \mathrm{L}^{-1}\right)$ & UA Found $\left(\mathrm{mmol} \mathrm{L}^{-1}\right)^{\mathrm{a}}$ & Recovery $(\%)$ \\
\hline & $5.00 \times 10^{-1}$ & $(9.10 \pm 0.21) \times 10^{-1}$ & 101 \\
$4.00 \times 10^{-1}$ & 1.00 & $1.43 \pm 0.32$ & 102 \\
& 1.50 & $1.86 \pm 0.28$ & 98 \\
& 2.00 & $2.42 \pm 0.34$ & 101 \\
\hline
\end{tabular}

${ }^{a}$ Results are expressed as mean value $\pm \mathrm{SD}$, based on five replicate. 


\section{Conclusions}

We have demonstrated the possibility of using the iron(II)-complex/MWNTs modified electrode for the simultaneous determination of UA, DA and AA. The modified electrode showed excellent sensitivity, selectivity and anti-fouling properties. The differential pulse voltammetry oxidation peaks for AA and DA, DA and UA, AA and UA are separated by 210, 136 and $346 \mathrm{mV}$, respectively. Therefore, simultaneous or independent measurements of the three analytes are possible without any interference. The proposed methods can be applied to the determination of DA, AA and UA in real samples with satisfactory results.

\section{Acknowledgments}

The authors wish to express their gratitude to the Zanjan University Research Council for the support of this work.

\section{References}

1. Martin, D. W. In Harper's Review of Biochemistry, Martin, D. W.; Mayes, D. A.; Rodwell, V. W.; $19^{\text {th }}$ ed., Lange: Los Altos, CA, 1983, p. 112.

2. Dryhurst, G.; Kadish, K. M.; Scheller, F.; Renneberg, R.; Biological Electrochemistry, Academic Press: New York, 1982, v. 1.

3. Martin, C.; Chem. Br. 1998, 34, 40.

4. Heinz, A.; Przuntek, H.; Winterer, G.; Pietzcker, A.; Nervenarzt 1995, 66, 662 .

5. Wightman, R. M.; May, L. J.; Michael, A. C.; Anal. Chem. 1988, 60,769A.

6. Safavi, A.; Maleki, N.; Moradlou, O.; Tajabadi, F.; Anal. Biochem. 2006, 359, 224.

7. Dayton, M. A.; Ewing, A. G.; Wightman, R. M.; Anal. Chem. 1980, 52, 2392.

8. Stamford, J. A.; Justice Jr., J. B.; Anal. Chem. 1996, 68, 359A

9. Zare, H. R.; Nasirzadeh, N.; Ardakani, M. M.; J. Electroanal. Chem. 2005, 577, 25.

10. Thiagarajan, S.; Tsai, T.-H.; Chen, S.-M.; Biosens. Bioelectron. 2009, 24, 2712

11. Da Silva, R. P.; Lima, A. W. O.; Serrano, S. H. P.; Anal. Chim. Acta 2008, 612, 89.

12. Jin, G. P.; Lin, X. Q.; Gong, J. M.; J. Electroanal. Chem. 2004, $569,135$.

13. Huang, J.; Liu, Y.; Hou, H.; You, T.; Biosens. Bioelectron. 2008, 24, 632 .

14. Atta, N. F.; El-Kady, M. F.; Galal, A.; Sens. Actuators, B 2009, 141, 566.
15. Kalimuthu, P.; John, S. A.; Talanta 2010, 80, 1686

16. Noroozifar, M.; Khorasani-Motlagh, M.; Taheri, A.; Talanta 2010, 80, 1657.

17. Atta, N. F.; El-Kady, M. F.; Galal, A.; Anal. Biochem. 2010, 400,78 .

18. Zhu, S.; Li, H.; Niu, W.; Xu, G.; Biosens. Bioelectron. 2009 , 25, 940 .

19. Kalimuthu, P.; John, S. A.; Bioelectrochemistry 2009, 77, 13.

20. Kumar, S. A.; Cheng, H. W.; Chen, S.-M.; Electroanalysis 2009, $21,2281$.

21. Ensafi, A. A.; Taei, M.; Khayamian, T.; J. Electroanal. Chem. 2009, 633, 212.

22. Kamyabi, M. A.; Asgari, Z.; Hosseini-Monfared, H.; Morsali, A.; J. Electroanal. Chem. 2009, 632, 170.

23. Iijima, S.; Nature 1991, 354, 56.

24. Ajayan, P. M.; Chem. Rev. 1999, 99, 1787

25. Wong, S.; Joselevich, E.; Woolley, A.; Cheung, C.; Lieber, C.; Nature 1998, 394, 52.

26. De Heer, W. A.; Chatelain, A.; Ugarte, D.; Science 1995, 270, 1179.

27. Baughman, R. H.; Cui, C. C.; Zakhidov, A. A.; Iqbal, Z.; Barisci, J. N.; Spinks, G. M.; Wallace, G. G.; Mazzoldi, A.; De Rossi, D.; Rinzler, A. G.; Jaschinski, O.; Roth, S.; Kertesz, M.; Science 1999, 284, 1340

28. Tans, S.; Verschueren, A.; Dekker, C.; Nature 1998, 393, 49.

29. Che, G. L.; Lakschmi, B. B.; Fisher, E. R.; Martin, C. R.; Nature 1998, 393, 346.

30. Dresselhaus, M. S.; Nature 1992, 358, 195.

31. Chen, P.; Wu, X.; Lin, J.; Tan, K. L.; Science 1999, 285, 91.

32. Kong, J.; Franklin, N. R.; Zhou, C. W.; Chapline, M. G.; Peng, S.; Cho, K.; Dai, H. J.; Science 2000, 287, 622.

33. Antiochia, R.; Lvagnini, I.; Magno, F.; Valentini, F.; Palleschi, G.; Electroanalysis 2004, 16, 1451.

34. Poh, W. C.; Loh, K. P.; Zhang, W. D.; Triparthy, S.; Ye, J. S.; Shen, F. S.; Langmuir 2004, 20, 5484.

35. Hrapovic, S.; Liu, Y. L.; Mall, K. B.; Luong, J. H. T.; Anal. Chem. 2004, 76, 1083.

36. Luo, H. X.; Shi, Z. J.; Li, N. Q.; Gu, Z. N.; Zhuang, Q. K.; Anal. Chem. 2001, 73, 915.

37. Lin, Y. H.; Lu, F.; Tu, Y.; Ren, Z. F.; Nano Lett. 2004, 4, 191.

38. Xu, Z.; Gao, N.; Dong, S.; Talanta 2006, 68, 753.

39. Wang, J. X.; Li, M. X.; Shi, Z. J.; Li, N. Q.; Gu, Z. N.; Anal. Chem. 2002, 74, 1993.

40. Cai, C. X.; Chen, J.; Anal. Biochem. 2004, 332, 75.

41. Wang, L.; Wang, J. X.; Zhou, F. M.; Electroanalysis 2004, 16, 627.

42. Zhao, G. C.; Zhang, L.; Wei, X. W.; Yang, Z. S.; Electrochem. Commun. 2003, 5, 825.

43. Cai, C. X.; Chen, J.; Anal. Biochem. 2004, 335, 285.

44. Zhao, Y. D.; Bi, Y. H.; Zhang, W. D.; Luo, Q. M.; Talanta 2005 , $65,489$. 
45. Salimi, A.; Hallaj, R.; Talanta 2005, 66, 967.

46. Musameh, M.; Wang, J.; Merkoci, A.; Lin, Y. H.; Electrochem. Commun. 2002, 4, 743.

47. Xu, Z. A.; Chen, X.; Qu, X. H.; Dong, S.; J. Electroanalysis 2004, 16, 684.

48. Gong, K. P.; Dong, Y.; Xiong, S. X.; Chen, Y.; Mao, L. G.; Biosens. Bioelectron. 2004, 20, 253.

49. Zhao, Y.; Gao, Y.; Zhan, D.; Liu, H.; Zhao, Q.; Kou, Y.; Shao, Y.; Li, M.; Talanta 2005, 66, 51.

50. Wang, J.; Musameh, M.; Lin, Y. H.; J. Am. Chem. Soc. 2003, 125, 2408.

51. Salimi, A.; Noorbakhsh, A.; Ghadermarz, M.; Anal. Biochem. 2005, 344, 16.

52. Salimi, A.; Mamkhezri, H.; Mohebbi, S.; Electrochem. Commun. 2006, 8, 688.
53. Constable, E. C.; Thompson, A. M. W. C.; J. Chem. Soc., Dalton Trans. 1992, 2947.

54. Wang, J.; Peng, T.; Vince, V.; J. Electroanal. Chem. 1987, 234 , 119.

55. Musameh, M.; Lawrence, N. S.; Wang, J.; Electrochem. Commun. 2005, 7, 14.

56. Salimi, A.; Mam-Khezri, H.; Hallaj, R.; Talanta 2006, 70, 823.

57. Bard, A. J.; Faulkner, L. R.; Electrochemical Methods, Fundamentals and Applications, Wiley: New York, 2001.

58. Fei, J.; Wu, K.; Yi, L.; Li, J.; Bull. Korean Chem. Soc. 2005 , $26,1403$.

Submitted: March 15, 2010

Published online: October 26, 2010 